\title{
Opening Online Academic Development Programmes to International Perspectives and Dialogue
}

\author{
Roisin Donnelly \\ Technological University Dublin, roisin.donnelly@tudublin.ie \\ Catherine Manathunga \\ TEDI, University of Queensland, Australia
}

Follow this and additional works at: https://arrow.tudublin.ie/ltcbk

Part of the Education Commons

\section{Recommended Citation}

Donnelly, R. \& Manathunga, C. (2009) Opening Online Academic Development Programmes to International Perspectives and Dialogue, In R. Donnelly \& F. McSweeney (eds.) Applied e-learning and eteaching in higher education, Hershey PA, IGI Global.

This Book Chapter is brought to you for free and open access by the Learning Teaching \& Assessment at ARROW@TU Dublin. It has been accepted for inclusion in Books/Book Chapters by an authorized administrator of ARROW@TU Dublin. For more information, please contact arrow.admin@tudublin.ie, aisling.coyne@tudublin.ie,gerard.connolly@tudublin.ie.

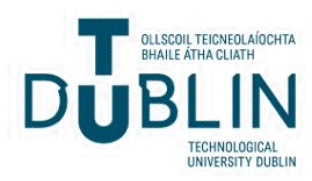




\section{Applied E-Learning and $\mathrm{E}-$ Teaching in Higher Education}

Roisin Donnelly

Dublin Institute of Technology, Ireland

Fiona McSweeney

Dublin Institute of Technology, Ireland 


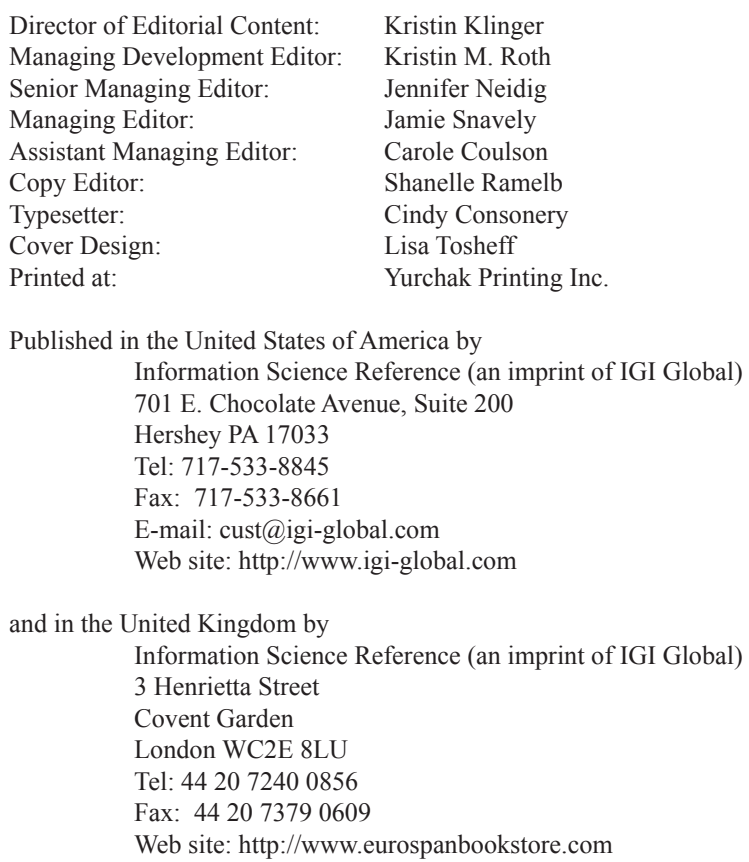

Copyright (C) 2009 by IGI Global. All rights reserved. No part of this publication may be reproduced, stored or distributed in any form or by any means, electronic or mechanical, including photocopying, without written permission from the publisher.

Product or company names used in this set are for identification purposes only. Inclusion of the names of the products or companies does not indicate a claim of ownership by IGI Global of the trademark or registered trademark.

Library of Congress Cataloging-in-Publication Data

Donnelly, Roisin.

Applied e-learning and e-teaching in higher education / [Roisin Donnelly, Fiona McSweeney].

p. cm.

Summary: "This book presents international practices in the development and use of applied e-Learning and e-Teaching in the classroom in order to enhance student experience, add value to teaching practices, and illuminate best practices in the area of e-Assessment. This book provides insight into e-Learning and e-Teaching practices while exploring the roles of academic staff in adoption and application"--Provided by publisher.

ISBN 978-1-59904-814-7 (hardcover) -- ISBN 978-1-59904-817-8 (e-book)

1. Universities and colleges--Computer networks. 2. Internet in higher education. 3. Education, Higher--Computer-assisted instruction. 4. Education, Higher--Effect of technological innovations on. 5. Information technology. 6. Educational technology. I. McSweeney, Fiona. II. Title.

LB2395.7.D66 2008

$378.1^{\prime} 7344678--d c 22$

2007051822

British Cataloguing in Publication Data

A Cataloguing in Publication record for this book is available from the British Library.

All work contributed to this book set is original material. The views expressed in this book are those of the authors, but not necessarily of the publisher.

If a library purchased a print copy of this publication, please go to http://www.igi-global.com/agreement for information on activating the library's complimentary electronic access to this publication. 


\title{
Chapter V Opening Online Academic Development Programmes to International Perspectives and Dialogue
}

\author{
Catherine Manathunga \\ TEDI, University of Queensland, Australia \\ Roisin Donnelly \\ The Learning and Teaching Centre, Dublin Institute of Technology, Ireland
}

\begin{abstract}
Professional development for academic staff in higher education is receiving increasing attention. The focus has been on providing an opportunity for academic staff to enhance their effectiveness in meeting changing needs and roles in higher education. Inherent in this changing role has been meeting the challenges of technology-infused learning environments available for use today. This chapter explores the potential of online academic development programmes to increase collaboration and dialogue amongst participants through integrating opportunities for online interaction. By spotlighting two particular postgraduate programmes in Ireland and Australia, the chapter reports on present experiences of integrating international guests and considers the future of connecting people and technology for academic development in higher education.
\end{abstract}

\section{INTRODUCTION}

Around the world, there are increasing university and government pressures on academic staff to engage in professional development to improve their teaching and learning practices (Gibbs, 2004; Kezar, 2001; Knapper, 2004; Knight, 2002; McAlpine \& Emrick, 2003). Demands are also 
being placed on academic development units to enable staff to realise the potential of flexible modes of learning for their students. Many higher education institutions have adopted an e-learning strategy whereby academic development is at the forefront of promoting adoption of new technologies to support learning and teaching. The Dublin Institute of Technology's (DIT) strategic plan illustrates this:

The common objective, in allelements of the Strategic Plan, is the achievement of excellence, through processes of continuous improvement of staff and programmes...to develop modularized eLearning programmes...to foster career development for staff...to train staff to deliver web-based and other learning programmes to students internally and externally in Ireland. (DIT Institutional Strategic Plan, 2001-2015, pp. 15, 17, 19, 21)

So, too, in the Australian context, the University of Queensland's (UQ) Teaching and Learning Enhancement Plan identifies "exploring new forms of educational interaction supported by information and communications technology" as part of its key goal of developing "flexible and engaging teaching practice," and commits the university to developing "a university approach to the support of Web-based teaching and learning materials and interactions" (UQ Teaching and Learning Enhancement Plan, 2003-2007, p. 8). Delivering on these kinds of imperatives requires those in academic development units to be increasingly creative and open to new perspectives and collaborative opportunities.

This chapter first explores the impetus for the creation and implementation of online academic development programmes, paying specific attention to the small amount of scholarly discussion on incorporating international guests into these fora. The challenges of running international online development are linked theoretically to models of professional development specifically for blended learning (the combination of face- to-face workshops and online learning activities and interaction). In particular, this chapter adapts Sharpe's (2004) professional development model for designing e-learning to these case studies. In order to set the scene for our experiences of involving international guests in our academic development programmes, the details of the contexts, curriculum design, and delivery of two diverse case studies are then presented. These case studies are in the fields of e-learning design and remote postgraduate supervision. In particular, we present evaluative data about these approaches based on a range of semistructured participant interviews from each programme over a period of 2 years. Finally, we discuss the implications of these teaching and learning strategies for academic development and for enhancing the international collaboration of academic developers. We also make some recommendations for future research directions.

\section{THE IMPACT OF E-LEARNING IN HIGHER EDUCATION}

The pressure to embrace e-learning technologies in higher education has arisen from a number of factors beyond the mere availability of increasingly sophisticated technologies. Of particular importance have been the learning preferences and styles of the so-called Internet generation, also known as Net Gen or digital learners (Donnelly \& O'Brien, 2003; Oblinger, 2006). The aptitudes, attitudes, expectations, and learning styles of these Net Gen students reflect the environment in which they were raised: one that is decidedly different from that which existed when academic staff were growing up (Oblinger \& Oblinger, 2005). As Oblinger continues to argue, today's younger student learners are digital, connected, experiential, immediate, and social with preferences for learning that include peer-to-peer interaction and engagement and for learning resources that are visual and relevant. So, too, in 
higher degree teaching and learning, a range of online technologies are increasingly available for postgraduate supervision purposes. Supervision in this case refers to the guidance of research students in Ireland, Australia, the United Kingdom, and other countries by academic mentors that are referred to as dissertation supervisors in Canadian and American contexts. An increasing number of research students are now enrolled in higher degree studies, including masters' in research and $\mathrm{PhD}$ programmes, that are at a distance from their supervisors and universities. In addition, many research students travel for extended periods of fieldwork and require ways of maintaining communication with their supervisors. Online supervision raises a whole range of diverse teaching and learning challenges that require very different supervision approaches from those used in face-to-face settings and for which ICTs offer great potential (Rodger \& Brown, 2000; Wisker, 2000).

It has been recognised that this increased uptake of e-learning technologies in both undergraduate and postgraduate coursework and for remote postgraduate supervision has not necessarily translated into excellent outcomes for all students (Ferrier, 1992). Indeed, there is still considerable apathy and confusion about the effectiveness of e-learning course delivery amongst students and academics alike (Shivkumar, 2006). Abrami, Bernard, Wade, and Schmid (2006) report that there has been scepticism about the use of technology to improve learning, including suggestions that it represents a threat to formal education. A number of studies report that students are dissatisfied with lecturers' use of technology for learning (Mering \& Robbie, 2005; Weaver, Chenicheri, \& Spratt, 2005).

In many cases, academic staff may seek to simply transfer the teaching techniques they are currently using to the new technologies, often with unsatisfactory results (Kearsley, 2000). Successful online teaching cannot be achieved by doing what lecturers always did in the classroom. In many respects, teaching online is not the same as teaching face to face. Supporting learning online through synchronous and asynchronous conferencing (bulletin boards, forums) requires teachers to have a wider range of expertise compared to working with face-to-face learning groups (Salmon, 2000). In the United States, Surry and Land (2000) suggest that enabling lecturers to use technology in their teaching means providing training that is motivating, attention gaining, and relevant, and results in confidence building. In particular, it has been demonstrated that online environments are far less conducive to didactic approaches to teaching and learning (Bowles, 2004).

In addition, Donnelly and O'Rourke (2007) argue that many academic staff lack the online experience of the Internet generation, and so do not feel as confident in an online environment as they do in a traditional classroom or postgraduate supervision setting. In this context, the problem is a social as well as a pedagogic one because it revolves around developing different kinds of communication skills and becoming adept at using the considerable array of available online communication tools. In many instances, lecturers may need to experience being an online student themselves in order to gain the necessary confidence to operate effectively in an online environment.

\section{INTERNATIONAL COLLABORATION IN BLENDED ACADEMIC DEVELOPMENT PROGRAMMES}

There is, therefore, a clear rationale for providing academic staff with professional development that allows them to enhance their teaching and learning practice and gain confidence in using elearning technologies simultaneously (Donnelly \& O'Farrell, 2006; Panda \& Juwah, 2006). There are a range of approaches to online academic 
development programmes already reported in the literature (Brew \& Peseta, 2004; Kandlbinder, 2000; Mainka, 2007). They include fully online programmes, such as that offered by the University of Sydney for postgraduate supervisors (Brew \& Peseta), and blended learning approaches incorporating both face-to-face and online components, such as the two programmes described in this chapter. So, too, they encompass fully accredited programmes, such as graduate certificates or diplomas in education, as well as voluntary academic development workshops.

All advertise similar benefits of increased flexibility and high-quality academic development support. Brew and Peseta (2004) indicate that evaluations of their online programme provided evidence of improved supervisory skills and greater knowledge of university postgraduate policies and processes. Kandlbinder (2000) argues that if online academic development programmes are designed to take an inquiry-focused approach, they are likely to "evolve into entirely new practices, in forms conducive to critical inquiry" (p. 376). More recently, an online professional development course at Napier University (Mainka, 2007) claims to provide opportunities for sharing prior knowledge, practicing new skills, supporting peers, and collaborating, and these can become the driving forces for empowering participants to identify the potential of technology in learning, teaching, and postgraduate research.

There is also a sense from the literature that some learning models driving academic development programmes in general are not making use of the shift in focus from "the sage on the stage" mentality of spoon-feeding knowledge to those who remain passive in the learning environment to the "guide on the side" concept of facilitating active and student-centred knowledge construction. Kandlbinder (2000) in particular refers to the tendency of some academic development units to adopt an information-centred transmission approach to online technologies. In order to achieve this shift toward student-centred learning, collaboration among students needs to be encouraged and modeled as an essential ingredient in effective teaching. As Harasim (1989) argued, students need to be "involved in constructing knowledge through a process of discussion and interaction with learning peers and experts" ( $p$. 51). Better use needs to be made of online academic development programmes to model these effective approaches to student learning for academic staff and to encourage them to discuss, argue, negotiate, and reflect upon their existing beliefs and knowledge about pedagogy.

The assortment of communication technologies made available in online programmes can enable this greater collaboration and interaction between academic developers and participants, and among participants. In particular, communication technologies, such as asynchronous discussion fora, synchronous chat sessions, and video and Web-cam interactions, broaden the pool of experts academic developers can include in their online programmes. Few scholars have investigated the impact of involving international guest lecturers in online programmes generally and in academic development programmes specifically. Referring to online student learning, ChanLin and Chan (2007) reported on the introduction of interdisciplinary experts into an online problembased learning (PBL) course. Students in this study reported that online interactions with their peers, the teacher, the facilitator, and these experts greatly enhanced their knowledge.

Janes (2000) wrote specifically about online academic development programmes, emphasising some of the benefits of linking with international guest lecturers in an online environment. These positive features included allowing participants in many countries, with varying experiences and levels of expertise in technology-based distributed learning, to share and learn from each other. Since the beginning of the certificate programme described by Janes, participants have visited 
each other on special occasions across cities or continents, collaborated on projects outside the course and after its completion, and coauthored papers based on their collaborative work in the courses, which have been published in peer-reviewed journals and conference proceedings. As a result, these opportunities often generate longterm teaching and research collaborations.

This chapter argues that the participation of international guest lecturers in online course discussions can allow academic developers to model for their academic participants active and studentcentred approaches to teaching and learning. In particular, through evaluative data collected from two diverse case studies in Ireland and Australia, we suggest that the involvement of international guest lecturers in academic development programmes provides additional opportunities for academic staff and their international guests to recognise, investigate, and critique their assumptions about teaching and learning; understand diverse international higher education contexts and perspectives; and enhance their capacity for clear communication and respectful, attentive listening. Developing such collaboration between courses in different institutions also allows academics to establish ongoing international research collaborations on e-learning and other areas of learning and teaching, and to embed academic developers themselves in a supportive, enriched community of academic development practice. The fact that these approaches are able to enhance academic staff learning in two very different forms of highereducation pedagogy (e-learning and remote postgraduate supervision) further substantiates these claims. Before we can outline these two case studies and because there has been so little written about incorporating international guest experts into academic development programmes, this chapter will now outline the professional development models for blended learning that we have adapted for use in designing our approaches to the two case studies.

\section{APPLYING PROFESSIONAL DEVELOPMENT MODELS FOR BLENDED LEARNING}

There are a number of models of professional development for blended learning and e-learning that we found useful in designing our approaches to interinstitutional collaboration. These models can be classified into the following categories.

1. Practice models, where examples would be Salmon's (2000) five-step model of online learning, Laurillard's (2001) conversational model, and the CSALT (Centre for Studies in Advanced Learning Technology, 2001) networked learning model.

2. Theoretical accounts developed in a research context and designed to provide coherent explanations of learning phenomena. Examples would be accounts written from the perspective of activity theory (Issroff \& Scanlon, 2005), cognitive and constructivist theories (Thompson, 2001), or theories of individual learning differences or styles (Sense, 2007).

3. Taxonomies and ontologies and other practical accounts exist that do not seem to fit any modeling framework such as case studies, action research reports (Zuber-Skerritt, 1992), projectfindings, or staff development materials. They are published through a variety of learning and teaching groups such as JISC (Joint Information Systems Committee) and the Higher Education Academy in the United Kingdom.

It is the third type of model listed above that has been selected for this book chapter because it seeks to explore the possibilities and problems inherent in interinstitutional academic development collaboration through a case-study methodology.

In supporting e-learning practice, Sharpe (2004) has proposed a typology consisting of 
consideration of the following characteristics to provide effective support for practitioners wishing to develop and design e-learning: usability, contextualisation, professional learning promotion, community work, and good learning design promotion. The curriculum design applied in these two online case studies addresses each of these categories, especially the issues of promoting professional learning and working within national and international academic communities. More recently, a six-stage generic model was developed for e-learning professional development (ePD) within the further education sector in the United Kingdom that is intended to support the raising of e-learning capability within the teaching and learning environment (Learning and Skills Network, 2007). With particular reference to an Australian context, Anderson and Henderson (2004) suggest a model within a pragmatic approach to extend the traditional boundaries of face-to-face training and sustain professional development for teachers in the use of e-learning. The key principles embedded in these models have also been applied in the construction of these two online academic development programmes, as will be highlighted below.

\section{INTERNATIONAL COLLABORATION IN ACTION}

Two case studies are presented: one from the Dublin Institute of Technology, Ireland, and one from the University of Queensland, Australia. The international collaboration that took place in both programmes will then be discussed in terms of designing relevant activities to maximise the effectiveness of the participation of the guest lecturers. The intention is not to directly compare the cases per se as the subject and contexts are different. Table 1 shows a number of key variables for the two cases as it is useful to see at a glance the scope of each module.

\section{Case Study 1: Designing E-Learning}

A postgraduate diploma module in third-level learning and teaching entitled Designing E-Learning is offered via blended delivery for academic staff in higher education in Ireland. Higgins and O'Keeffe (2004) speak of effective e-learning and good content, and express a belief that most if not all learners learn best through blended learning.

Table 1. The scope of the two case studies

\begin{tabular}{|l|l|l|}
\hline Module Title & Designing E-Learning & $\begin{array}{l}\text { Remotely Interested: Supervising Off- } \\
\text { Campus Research Students }\end{array}$ \\
\hline Number of Participants & 17 academic teachers & 27 postgraduate supervisors \\
\hline Context & $\begin{array}{l}\text { Irish higher education Academic } \\
\text { development Postgraduate diploma } \\
\text { programme on e-learning }\end{array}$ & $\begin{array}{l}\text { Australian higher education } \\
\text { Academic development } \\
\text { programme on remote supervision }\end{array}$ \\
\hline Virtual Learning Environment & WebCTTM & BlackboardTM \\
\hline Other Technologies in Use & $\begin{array}{l}\text { Audio tools } \\
\text { Blogging } \\
\text { Discussion forum \& chat } \\
\text { Interactive whiteboard } \\
\text { Videoconferencing }\end{array}$ & $\begin{array}{l}\text { Discussion forum } \\
\text { Online quizzes }\end{array}$ \\
\hline Online Activities & $\begin{array}{l}\text { Individual } \\
\text { Paired } \\
\text { Small-group problem-based } \\
\text { learning }\end{array}$ & $\begin{array}{l}\text { Individual, self-paced learning } \\
\text { discussion }\end{array}$ \\
\hline
\end{tabular}


Blended learning, as the name suggests, consists of a blend of at least two pedagogical approaches. Within the context of this Irish case study, blended learning is the integration of the face-to-face PBL in a classroom with e-learning technologies. For example, the classroom is used by the PBL group to discuss critical concepts, and the discussion boards, e-mail, and synchronous chat room in the online environment WebCT are used to encourage the international dimension to participant dialogue around the concept. In addition, where relevant, guest lecturers have recommended resources for the e-library and provided important contextual and background information for their profile area. See Figure 1 for an illustration of the module design, with specific components that have been utilised for international collaboration highlighted in blue. There are four main components to the online site: resources, module information, the PBL collaborative area (where the participants and the guest lecturers dialogue), and the prob- lem work space (where the participants work iteratively together to produce the end product of the module).

This module is part of an accredited professional development programme for academic staff. A specific approach was taken to the design and delivery of this module by using PBL as the dominant pedagogical model. An international dimension was integrated into the design of the problem by introducing online collaboration with peers in Australia over the 10 weeks of the module's duration.

Activity features at the heart of the design of the module. Communication and collaboration activities in the module included peer, lecturer, and international guest-expert communications, which all supported the participants in their questioning, challenging, and constructing of knowledge about the design of e-learning. Strands of recent thought about effective learning and professional development stress the primacy of peer

Figure 1. Schema of the international dimension to the designing e-learning module

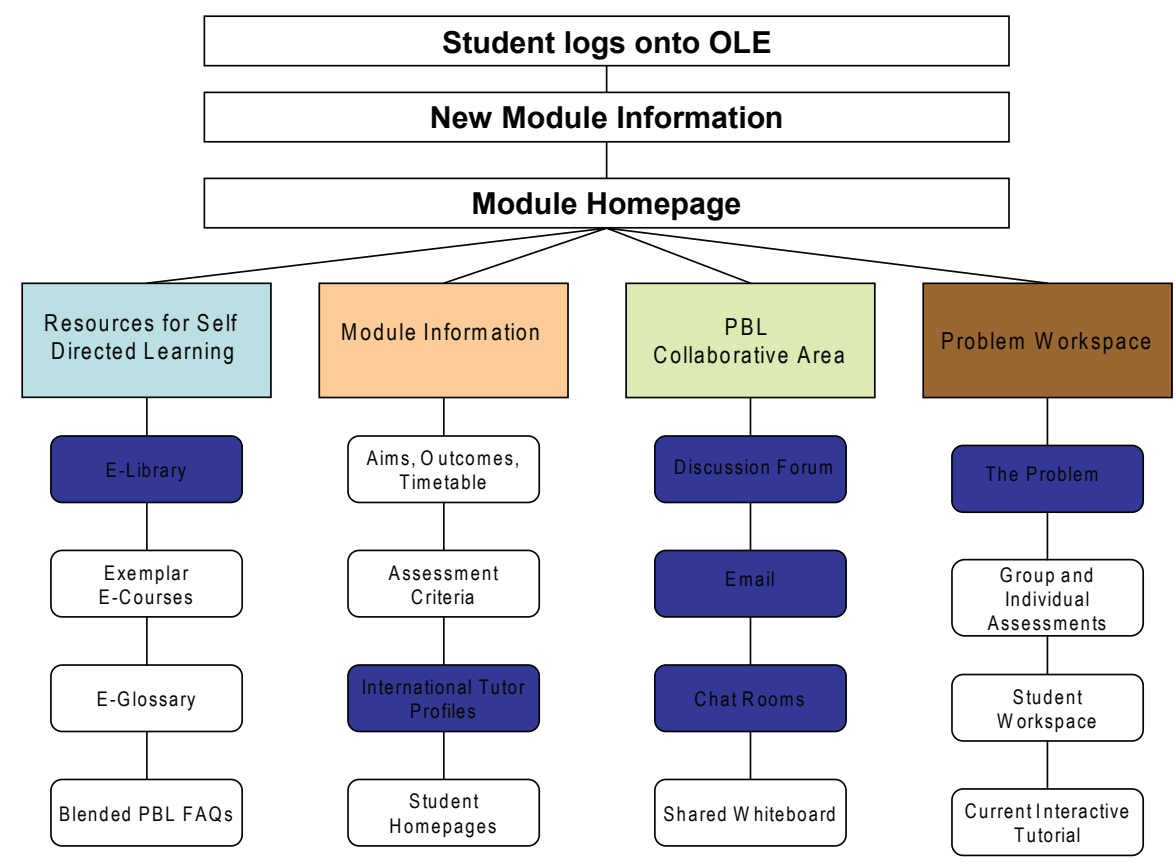


interaction, continuing reflection, the importance of experience, and the grounding of theory in practice (Kolb, 1984; Schön, 1990; Wenger, 1998). Figure 2 shows the different levels at which activity takes place. Participants begin the module with a number of activities designed to allow them to become well acquainted with each other and build trust and collegiality in their PBL groups. This evolves into a widening of perspectives by interacting with international guest lecturers. Central to this is the sharing of experience and perceptions as academics working in different disciplines, but all with the same intention of wishing to design e-learning and PBL courses. Tasks have been designed to enable the participants to engage with conceptual frameworks in the field of e-learning and PBL, and through the PBL experience, they begin the journey of applying theory to practice. The tools used to support this learning process are asynchronous discussion boards, synchronous chat rooms, reflection through blogging software, and the face-to-face PBL tutorial itself.
Liberman (2000) believes that the building of teacher networks or communities is increasingly seen as a way of fostering the conditions in which this type of development can take place. An experiential view of learning informs the way we, as academic developers, design and modify our courses as we believe that there is no substitute for our own experience delivering these courses. However, inherent in this is our belief in providing ourselves with opportunity for reflection and research and to allow both to feed into subsequent stages of course design.

\section{Case Study 2: Supervising Off-Campus Research Students}

An online module on remote supervision, entitled Remotely Interested: Supervising Off-Campus Research Students, is offered as part of a nonaccredited academic development programme on postgraduate supervision at an Australian university. This full-year programme, Becoming

Figure 2. Activity in the module

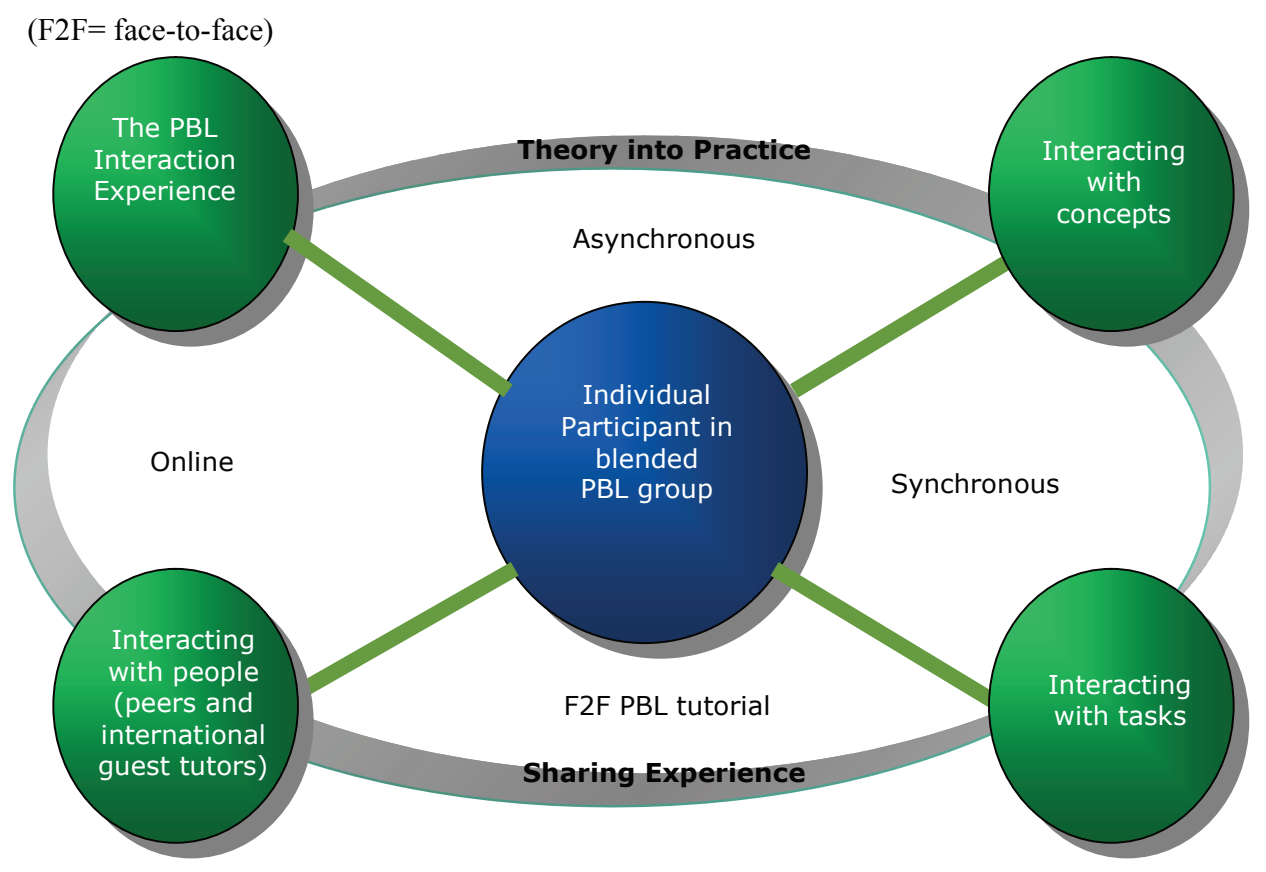


an Effective Supervisor, also adopts ablended approach to learning, containing three face-to-face interactive sessions on aspects of postgraduate supervision, one online e-learning module, and one mentoring module based within the participants' school or disciplinary area. The content and style of delivery are deliberately matched, particularly in the online module, which is about the pedagogical issues and strategies involved in supervising students from a distance using the growing array of available online technologies (Manathunga, 2002). In Australia, off-campus research students are officially classified as remote. They may be off-shore or international students who are located at some distance from the campus; they are enrolled in or based externally due to work and/or family commitments.

The rationale for this module is derived from a number of factors. First of all, remote or online supervision is likely to become an increasing feature of postgraduate supervision work for many supervisors as more international students elect to remain in their own countries while undertaking higher degrees in research and as mature-age students with a range of work and/or family commitments increasingly enroll in research studies. Even for on-campus students, the availability of a myriad of e-technologies that can support postgraduate supervision has led to a rapid increase in supervision via e-mail, online chat sessions and discussion fora, and a number of Web-cam technologies. Second, many supervisors lack experience in online teaching and technologies, and this module presents them with the opportunity to engage in online learning. The module participants are also from a range of disciplinary and professional backgrounds, including the health sciences, sciences, engineering, social sciences, and humanities. While the programme is largely designed for new or intending supervisors, many participants have supervised research students for considerable periods of time, ensuring that there is a full spectrum of supervision experience levels in the group. In this particular module, some su- pervisors are al ready supervising remote research students while others are interested in future remote supervision; others supervise students who engage in lengthy periods of fieldwork and require extended periods of remote guidance.

In a similar way to the design of the Designing E-Learning module described in Case Study 1, the 2-week module on remote supervision requires the participants to engage in a range of activities, including reading course materials and readings, listening to example audio files, and engaging in online activities in the discussion forum (see Figure 3). In the first week of the module, which explores the issues students and supervisors face in remote supervision, former remote student and supervisor Dr. Ted Brown along with Associate Professor Sylvia Rodger joins the discussion forum. Rodger and Brown (2000) jointly wrote "Enhancing Graduate Supervision in Occupational Therapy Education through Alternative Delivery," which is used as a key reading in this part of the programme. They are able to provide the participants with additional insights into these issues from personal experience and from the research they conducted for this article. Figure 3 outlines the three main components of the online Web site. These include resources for self-directed learning, which are described above; tasks and modules, which explain the programme's stimulus material and online activities; and communications, where lecturers, participants, and national and international guest lecturers carry out the online activities and discussion. Figure 3 has also highlighted the location of the specific national and international components within the programme.

Strategies for effective remote supervision are explored in the second week of the module and are supported by the involvement in the discussion forum of Professor Roly Sussex, who provided an example audio file as an indication of the ways technology can be used to provide remote research students with feedback on their writing. It is also at this point in the programme 
Figure 3. Schema of the international dimension to a module on remote supervision

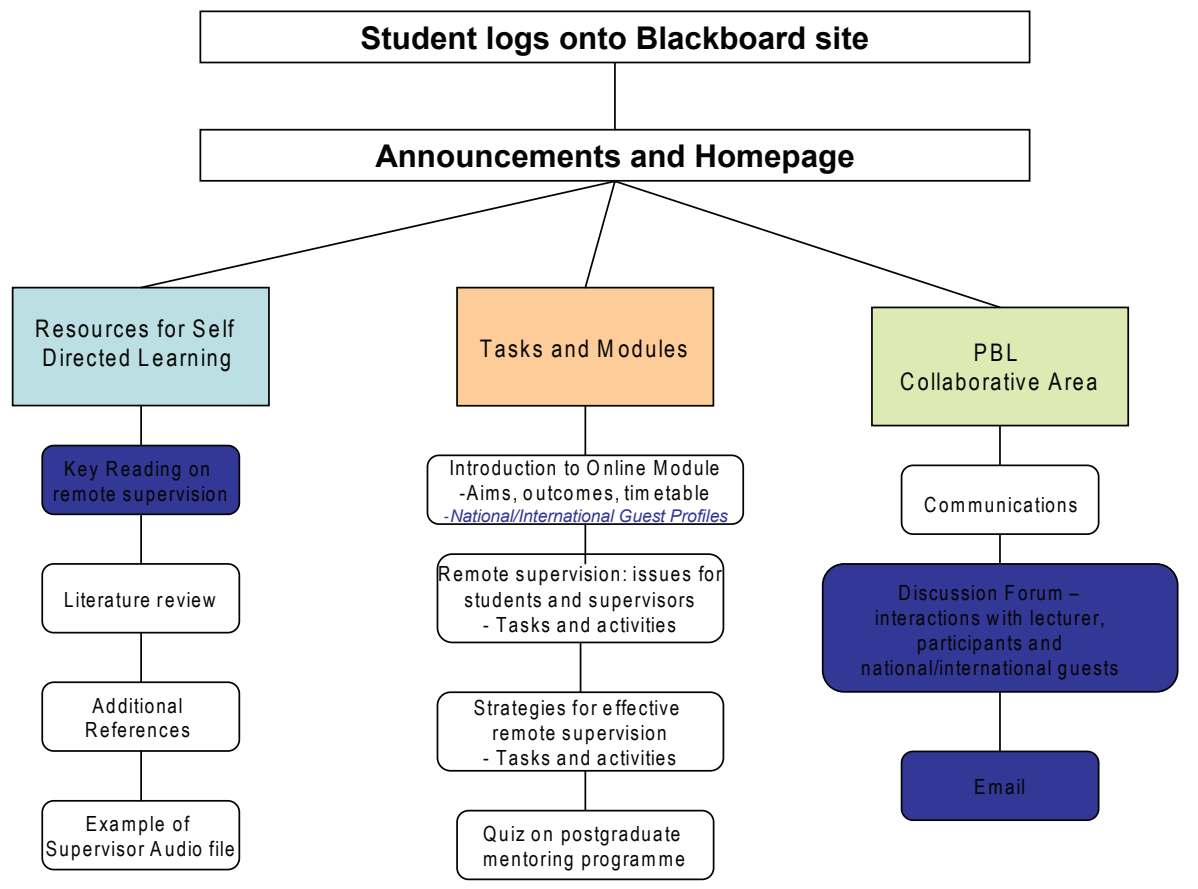

that one of the authors, an Irish practitioner on e-learning and my coauthor in this book chapter, joins the discussion forum and provides advice on the use of innovative technologies for effective remote supervision. When the programme was conducted in 2005 and 2006, she was also a remote doctorate student herself, ensuring that she could provide additional insights into the issues faced by remote research students (see Figure 3).

\section{Evaluation of the International Collaborative Approach}

Networking with other academics and academic developers internationally is a strong feature of these modules, and practice in designing e-learning and e-supervision is enhanced by the multiple perspectives this collaboration brings. In recent years, through the Designing E-Learning module, communities of practice have been developed with colleagues in Scotland, Finland, and most recently, Australia. In the Remote Supervision module, international online collaboration has occurred at several locations within Australia and with Ireland. The essence of these modules involves participants being brought together by joining in common activities.

In the first case study, the group meets online with the asynchronous feature of the online learning environment WebCT, which is designed to scaffold participants as they organise their PBL group task then synthesise, post, and critique the results of their deliberations. Real-time online events occur throughout this model through the WebCT Synchronous Chatroom tool, which is used for problem-solving areas of the curriculum so that the lecturer can help students on a oneto-one or one-to-small-group basis. In the second 
case study, participants are joined by national and international guest lecturers from Melbourne and Ireland in the asynchronous discussion forum provided by Blackboard. In both cases, participants interact with each other through posting e-mail and discussion-board questions. The strengths of this approach are the online collaborative discussions, presentations by participants, and interaction between online lecturers, participants, and international guest lecturers from Australia and Ireland.

The purpose of an asynchronous link via a discussion board was to rejuvenate the groups' work and discussions by introducing, in the first case, two guest lecturers from TEDI in the University of Queensland, Australia, and, in the second case, guest lecturers from Monash University in Melbourne, Australia, and the Learning and Teaching Centre in the Dublin Institute of Technology, Ireland. Through such expansion of physical classroom boundaries, an MP3 audiofile adds live interaction to asynchronous distance learning. Such guest lecturers can be invited in to join the conference so students can interact directly with experts in their fields (Cotlar \& Shimabukuro, 1995).

In the first case study, some of the varied interactions between participants and international guest lecturers included discussions about how to assess online participation, how guest lecturers can keep up with the volume of online postings, how to maintain participant motivation for e-learning and collaborative learning, how to make the most of e-learning in visual disciplines, the use of online role play, and how a guest lecturer can pick up on early signs of problems for first-year students.

The inclusion of one short vignette of guestlecturer intervention in online discussions clearly shows the development of a key issue in the Designing E-Learning module. The topic that arose for discussion centred on the cause and impact of online bullying between students.
Participant: These questions have being troubling me since I started reflecting on my experience as an online student. How does or can a lecturer recognise online bullying, is it peer pressure or intimidation?...could silence or non/minimum participation in online chats and discussions be perceived as peer intimidation if for no other reason than a lack of confidence by the timid individual? [In a group learning scenario] can people who seemingly reply to each other on an individual basis throughout all online discussions be seen as not listening to the other individuals in the group? It would appear that seeing a friendship form F2F is more acceptable and obvious than seeing it form online.

Tutor: I think you've raised really important and difficult issues that are so different from face-toface teaching. I think it is extremely difficult for us as lecturers to recognise online bullying, peer pressure and intimidation. There's also the whole issue of lurking and silence and what that means and how we interpret it. Silence can mean all sorts of things like busy workloads (like you say), wanting to reflect and respond to a full debate at the end, lacking confidence, lurking and getting lots from the conversation and using it in other ways etc.

For some quieter people, the online environment is great because they can carefully construct their responses and re-read them to make sure they make sense before sending them and it means they don't have to try and jump into fast free-flowing discussions like you do in face-to-face settings. I've heard that students whose second language is English often feel more comfortable with email and other online types of communication for those reasons.

Participant: Thanks! You have given me a new insight into how online responses or lack of does not always mean that the individual is being negative or over controlling. The tutor's [lecturer's] responses has now prompted me to think about my own personality and how I might be perceived online by others in my learning group. 
In addition, by sharing a number of professional and personal experiences with this participant, one of the authors was able to convey her meaning about the important issue of online bullying in a coherent and meaningful way.

The use of audio messages in this module was well received by the participants:

Thank you for your very generous contributions and the wonderful sites and knowledge you have given us. I have just finished listening to the recorded messages. The use of the MP3 gives another dimension to eLearning, as it brings the other person to life. (online posting from DIT module participant, 2006)

One guest lecturer introduced us to the use of an MP3 Player to record her responses and provided the group with audio feedback to individual questions. At first I did not see the value of this and assumed it as a gimmick rather than a teaching technology to aid learning. Inow believe that the wizardry of delivery tools can be used to complement instructional design. It was only after the event that I discovered how extremely important the voice recordings were and saw this as an alternative to live chat and video conferencing.
Replacing the typed word with voice recorded messages could make participation easier for some of my students, who can feel embarrassed by the type of difficulties they struggle to cope with such as literacy skills, slower mental processing, attention and organisational difficulties which can lead to internalized negative labels which can result in a lack of confidence. The students can verbally express their perspectives using the audio recordings and can instantly record their thoughts and feelings. (online reflective posting from DIT module Participant, 2006)

In the second case study, a range of remote postgraduate supervision issues were debated by the lecturer, participants, and the national and international guest lecturers. Table 2 describes this list of topics when the module was delivered in 2005 and 2006.

As a result of the debate, participants were able to gain many useful insights into the issues and dilemmas associated with this breadth of topics and learn about a variety of effective online supervision strategies and technologies from national and international experts. As one participant in this module indicated, national and international guest lecturers helped students "consider some

Table 2. Online interactions with national and international participants

\begin{tabular}{|c|c|}
\hline 2005 & 2006 \\
\hline $\begin{array}{l}\text { Missing subtle nonverbal cues about students } \\
\text { having difficulties } \\
\text { Recommended frequency of contact with } \\
\text { remote students } \\
\text { Positive aspects of remote supervision (written, } \\
\text { recorded interaction, international collaboration, } \\
\text { etc.) } \\
\text { - Research methodologies in online courses } \\
\text { Modes of interacting with remote students } \\
\text { including audio and video }\end{array}$ & $\begin{array}{l}\text { - } \text { Costs for students of remote vs. face-to-face } \\
\text { study } \\
\text { - } \quad \text { Keeping student motivated and procrastination } \\
\text { issues } \\
\text { - } \quad \text { Required continuity of contact } \\
\text { - } \\
\text { - } \quad \text { associatiating with remote principal and local } \\
\text { - } \quad \text { students given their other responsibilities } \\
\text { - } \quad \text { student issues } \\
\text { - } \quad \text { Ureaking the ice with remote students } \\
\text { - } \quad \text { Using audio for supervision interactions } \\
\text { interaction }\end{array}$ \\
\hline
\end{tabular}


of the complexities remote students have to face when conducting their research away from a traditional campus setting" (Remote Supervision module participant, 2006).

\section{Benefits of the International Collaborative Approach}

Open-ended qualitative questionnaires were used in both modules to collect evaluative data and selected quotes from participants are included to illustrate the range of perceived impacts felt by the participants as each module came to a close. Participants emphasised some key benefits in using the international collaborative approach adopted in the two cases: including the provision and broadening of multiple perspectives, opening up the potential for networking, expanding the sense of being part of an international community of practice, and very importantly tackling the issue of isolation that many academics feel in their practice, revealing that colleagues from other countries and disciplines were also facing similar problems and coming up with strategies to cope with them. Each is now discussed in more detail with supporting evidence from the qualitative questionnaires.

Interacting with peers from higher education institutions internationally was regarded as important for providing multiple perspectives to learning collaboratively: "Being in a blended community of like-minded individuals was a positive and exciting experience- especially having international guest professionals. Experiencing live video conferencing, online discussions, and podcasting have left me with a great sense of achievement as a learner" (DIT module participant, 2006).

Bringing internationality into the groups to discuss the variety of ways of using different media in education proved highly influential to broadening perspectives for the participants in the module: "It was wonderful to be able to communicate with such knowledgeable academ- ics from halfway round the world" (DIT module participant, 2005). Another participant said,

What I really enjoyed was having other people coming in to speak with us. For example, the international guest tutors [lecturers] who joined our online discussions, which was a huge input and gave us great variety in our debates on topics. They introduced new perspectives and a touch of the exotic to our learning. (DIT module participant, 2005)

Similar feedback was received from 2005 and 2006 participants in the Remote Supervision module. In particular, participants emphasised the effectiveness of guest lecturers: "Hearing the perspective from people from other institutions and also from people from different countries provides new perspectives and insights...and dimensions" (Remote Supervision module participant, 2005).

They also suggested that national and international guest lecturers provided an

opportunity to see how other institutions (and individuals) manage remote student supervision. They gave me suggestions for managing remote students that I had never previously considered, e.g. using online chat [and] ...helped me to appreciate other ways in which students and supervisors can interact. (Remote Supervision module participant, 2006)

An external evaluator of the module on remote supervision also emphasised the value of incorporating multiple international perspectives. In particular, she commented on the pedagogical benefits of including "remote students and experienced supervisors...(including a supervisor of students whose second language is English, who also has suggestions for new and innovative technological tools) and an online learning expert, who are all able to contribute different perspectives on remote supervision" (external evaluator, 
UQ module, 2006). She also highlighted the vast potential for networking and broadening the sense of being part of an international community of practice. She commented, "The effect of having an expert based in Ireland and on leave in Spain is to extend the 'research community' and suggest the benefits of online access." Similarly, the external examiner for the Designing E-Learning module drew attention to the importance of the international collaboration between module participants and the international guest lecturers: "From the participants' perspective, this is an innovative and exciting use of the technology to place their learning in an authentic academic context and enhance their experience of eLearning; they are truly seeing the value that technology can bring to a learning event."

Another benefit identified by participants in the Remote Supervision module was the reassurance that remote students and supervisors all around the world were dealing with similar problems and challenges. As one participant indicated,

If the same problems are encountered by people across the board (including external and international participants) then it adds to the evidence that some issues might be universal and not just due to problems/oversights/procedures at your own university. So essentially [this] ... allows you to evaluate better the "uniqueness" of the issues encountered (i.e. common, institute-specific, field-specific etc)....[It] might not help you to solve the issue but makes you feel better if you know everyone has the same problem;-). (Remote Supervision module participant, 2006)

The technology also facilitated a burgeoning network within the module and beyond with the international guest lecturers, and this is potentially a positive force for change in practice. The participants themselves believe that digital technologies will progressively extend opportunities to engage in collaborative reflective PBL practice across disciplines:
For me the video conferencing sessions on the module with the international guest tutors [lecturers] were activating events for my learning. We had things in common with them as fellow educators and they got us to consider key learning issues as their postings were very deep and really got you to think through an issue. We continued to liaise with them for weeks after the module closed and one of the Australian tutors [lecturers] invited us to participate in their own online courses with fellow teachers from there. (DIT module participant, 2006)

\section{Limitations of the International Collaborative Approach}

It is also important to highlight some of the limitations involved in inviting external national and international guest lecturers into online academic development programmes. First, a sense of pressure can pervade both sides of the online communication. In interacting with experts from a discipline, participants in a module can feel they are under scrutiny. There can also be pressure for international guest lecturers inherent in dealing with what can be a large number of often vague queries from participants. This can make it difficult to craft suitable responses for each participant query when, quite often, the guest lecturers are brought into the module after it has begun and are lacking knowledge about participants' contexts and backgrounds. Also, technical problems can arise at any time, and timetable issues can be a problem, especially if the international guest lecturers are from different hemispheres. Each of these limitations is now discussed in more detail with supporting evidence from the qualitative questionnaires.

While participants in the Remote Supervision module did not identify any problems with the involvement of national and international guest lecturers, it is possible to reflect upon the nature of some of the online interactions between participants and guests and to draw upon our own 
experience of being international guests. Some of the initial interactions between participants and guests in the Remote Supervision module appear to suggest that participants can feel under pressure, at least at first, to think of something to ask the international guest just to make them feel welcome and included in the online dialogue. This can result in veryopen-ended requests for information or perspectives. For example, one participant asked the guest lecturer, "From your experience, do you have a list of suggested online activities that work well for interactions between students and advisors? Are there some activities that do not work well?" (Remote Supervision module online discussion forum, August 15, 2006). The guest lecturer, in her response, clearly recognised the underlying purpose of the question and acknowledged the invitation to join the discussion by the participant: "many thanks for the question, and for bringing me into your discussion this week" (Remote Supervision module online discussion forum, August 16, 2006). It was important to recognise that such a broad question needed to be broken down in order to give a focused and meaningful response. However, this question was able to generate considerable further discussion and debate and, in many senses, even face-to-face discussions often begin broadly and then delve down into specific issues and perspectives.

Looking at this same issue from another perspective, it can also be difficult to avoid the discussions that may simply be a one-way channeling of resources and advice from experts by participants instead of a two-way exploration of key issues. In the Designing E-Learning module, a number of participants opened their dialogue with such requests.

What are your views and advice re the evaluation of eLearning courses and can you suggest some useful websites?

I've two questions I'd like to askyou. It would appear from the volume of literature from Australia in the field of online learning that you guys are pretty much world leaders in this. Is that so? The other thing I'd like is any resources you can give on learner assessment. (online postings from DIT module participants, 2005)

It is important to convey to participants that the opportunity for collaboration need not turn into an inquisition. One participant in particular set a series of long and sometimes very disciplinespecific questions for the guest lecturer.

I have been wondering how difficult is it to start an online module or programme if there has been no experience of it in one's institute. What do you feel are the initial essential requirements? Are there real benefits for the Management?

What type of assessment works best in a learning support site such as ours?

I find the on-screen comments can be a little condescending after a while. Is there another method of feedback that is low on labour, yet effective?

Is online learning very popular "down under"? Has it been successful in construction education?

Do you have any research on what students think before, during and after information skills online modules? (online postings from DIT module participants, 2005-2006)

From a participant perspective also, there may exist what can be termed a novice-expert gap. In the Designing E-Learning module, some of the participants who had previously identified themselves as novices as regards their knowledge or experience of e-learning were initially wary of electronic discussion exchange with the guest lecturers and expressed fears of appearing inadequate in the public discussions in front of the international experts: "The guest lecturers 
posted encouraging introductory messages and these removed my fear of interacting with expert practitioners in the eLearning field. I learnt that the human touch is possible in this environment despite the cool nature of electronic delivery" (online posting from DIT module participant, 2006).

However, as suggested here, this can be tempered by a thorough introduction made by the experts to the participants highlighting their own journey on this pathway. Once this unease is overcome, the participants settle into a mutual development of ideas with the guest lecturers: "We look forward to your comments; it's really great to have an international dimension to our learning" (online posting from DIT module participant, 2006).

As an international guest, you can feel like you lack a lot of information about the participants' contexts and backgrounds. This can create concerns that you may be overly general or simplistic in your response or that you may have given a response that is completely irrelevant to the participants' contexts. As an international guest, one of the authors has felt that she has had to rely on the patience and good will of the participants to respond generously to her lack of understanding about their context and issues. In particular, this highlights the need in online academic programmes for cultural sensitivity and an understanding of educational practices in other countries (MacKinnon \& Manathunga, 2003). These intercultural communication skills are, however, a vital part of teaching and researching in globalised higher education and, as a result, provide participants with an excellentopportunity to enhance their own skill levels.

In some ways, these limitations can be partly addressed by incorporating in the module content as much information as possible about the background and expertise of both the international guests and the participants. It also helps to provide the international guest with an indication of the projects or assessment topics being explored by participants. As outlined in Figures 1 and 3, the authors have factored these considerations into the design of their online modules. The other way these issues can be addressed is to emphasise the importance of generosity, patience, respectfulness, and good will in online discussions. While these characteristics assist in the effective flowing of discussion in any face-to-face session (especially in intercultural learning settings), they are even more vital in online programmes, where misunderstandings may more easily occur because of a lack of nonverbal and other contextual information.

On a more pragmatic note, there may be a number of technical difficulties and limitations involved in incorporating national and international guest lecturers into online academic development programmes. One of the significant things we have learnt about online technology is to try and keep it simple. Technical problems tend to grow when crossing country borders. However, these difficulties are gradually being resolved as the technology develops. For example, until quite recently, videoconferencing was an expensive, labour-intensive, and unreliable technology. Over the past 5 years, this has dramatically changed so that now video over IP (Internet protocol) has become cheap, simple, and effective.

Time-tabling can also prove to be another obstacle. Many different course-calendar arrangements exist in our international academic world, making joint time-tabling quite a hassle. In addition, different time zones, even in asynchronous online communication, can sometimes create confusion and may increase expectations of how long international guests need to be involved in online discussions.

\section{DISCUSSION}

Embedding an international dimension in the learning and teaching process, with special reference to the potential role of ICT in that process, is 
more complex than it first appears. Whilst theoretical models of professional development (e.g., Sharpe, 2004) emphasise a number of different levels such as usability, contextualisation, professional learning promotion, community work, and good learning-design promotion, we have found in practice that integrating international collaboration needs to be infused throughout all aspects of curriculum design. Through international collaboration between participants on academic development programmes, there certainly is potential to contribute to the creation and translation of knowledge about learning, teaching, and supervision. This contributes toward a flexibility of bridging across structures in such social and academic networks. We believe that the model of exchange between participants and guest lecturers in both case studies has been fruitful in unpacking the relationship between theory and practice in the pursuit of knowledge about learning, teaching, and remote supervision.

The value of international collaboration as experienced in the cases detailed in this chapter is illuminated through a consideration of how the educator can design relevant discussion activities to enhance the engagement of the guest lecturer(s) with the module participants. Brookfield and Preskill (1999) have claimed for many years to be unwaveringly committed to teaching through discussion and point to the benefits consistently enjoyed through practice. Of the 15 advantages the learner experiences from participating in discussion, a number have appeared in these case studies, particularly as evidenced by the participant quotes previously: an increase in the breadth of discussions, participants becom-

\section{Table 3. International online critical discourse}

\begin{tabular}{|l|c|l|}
\hline \multicolumn{1}{|c|}{ Value of International Online Discussions } & \multicolumn{1}{c|}{ Relevant Activities } \\
\hline Helps participants recognise and investigate their assumptions & $\begin{array}{l}\text { With the group's knowledge and permission, assign } \\
\text { different roles to participants with some being asked to be a } \\
\text { respectful "devil's advocate" } \\
\text { Encourage international guest lecturers to respectfully } \\
\text { unpack } \\
\text { participant's implicit assumptions about e-learning or } \\
\text { remote supervision }\end{array}$ \\
\hline Encourages attentive, respectful listening & $\begin{array}{l}\text { Set ground rules for respectful communication in the course } \\
\text { Model inclusive practice and respectful listening in the } \\
\text { lecturer's own postings }\end{array}$ \\
\hline Helps participants explore a diversity of perspectives & $\begin{array}{l}\text { Deliberately choose international guest lecturers who you } \\
\text { know have very different perspectives from your own }\end{array}$ \\
\hline $\begin{array}{l}\text { Increases breadth and makes participants more empathetic to } \\
\text { the experience of online students }\end{array}$ & $\begin{array}{l}\text { Ask students or former students to join in discussions of } \\
\text { online learning } \\
\text { Provide case studies and readings that highlight students' } \\
\text { experiences of online learning }\end{array}$ \\
\hline Shows respect for participants' voices and experiences & $\begin{array}{l}\text { Set ground rules for respectful acknowledgement of } \\
\text { participants' perspectives }\end{array}$ \\
\hline Helps participants develop skills of synthesis and integration & $\begin{array}{l}\text { Model how to effectively summarise and weave together } \\
\text { participants' postings in the lecturer's contributions to } \\
\text { online discussions }\end{array}$ \\
\hline $\begin{array}{l}\text { Increases participants' awareness of and tolerance for ambiguity } \\
\text { or complexity in a topic }\end{array}$ & $\begin{array}{l}\text { Deliberately choose international guest lecturers who you } \\
\text { know have very different perspectives from your own } \\
\text { Present arguments for and against the use of particular } \\
\text { online technologies to prompt debate and higher order } \\
\text { understanding }\end{array}$ \\
\hline
\end{tabular}


ing aware of the need to be more empathetic to the experience of online students, participants becoming connected to a topic, and raised awareness by participants of tolerance for ambiguity or complexity in a topic. Table 3 shows all the rewards experienced by participants in the online discussions. Recognising the importance of critical discourse within professional development, it is argued that experiencing these benefits can lead toward improvement in academics' approaches to e-learning and e-teaching.

As a result, participants are given the opportunity to engage in the final two stages of Salmon's (2000) model of computer-mediated conferencing: knowledge construction and development. This is not only valuable for students' own learning aboute-design or remote supervision, or whatever topic the academic development programme is emphasising. It also models for them how effective e-moderators can encourage students to reach these higher order levels of engagement in online learning. Therefore, their comfort levels with online technologies are greatly improved (Donnelly \& O'Rourke, 2007) and their own approaches to online teaching and learning are enhanced through experiential learning (Biggs, 1999; Brookfield, 1990). In particular, this experiential form of academic development enhances academics' ability to respond to the learning needs of the Internet generation and to make the most of the pedagogical and technical possibilities afforded by e-learning technologies (Oblinger, 2006; Oblinger \& Oblinger, 2005; Seely Brown, 2000).

Specifically, the academic participants experience firsthand the benefits of incorporating external national and international guest lecturers in online programmes and are, therefore, more likely to adopt this approach in their own online teaching. This chapter confirms the work of Janes (2000) on the value of linking with international guest lecturers in an online environment. It has provided evidence from the voice of the participants themselves as to the coherence and depth reached in their online discussions. It also extends
Salmon's (2000) ideas about how to broaden online conference experiences, in particular by the provision of examples of online discussion activities to attain critical discourse amongst a group of interdisciplinary participants.

Academic participants involved in online academic development programmes that incorporate national and international guest lecturers also have the potential to develop ongoing teaching and research partnerships with academics around the world, as Janes (2000) also found. This chapter reveals a number of case studies of such long-term international collaboration. This is beneficial to encourage long-term partnerships among academic staff working in disciplines. It also enables the building and strengthening of academic developers' knowledge and enhances the effectiveness of the academic development international community of practice.

Teaching in higher education has often been characterized as an isolated activity, yet opportunities for lecturers to work and learn together are slowly increasing. Underlying this shift is the view that as academic staff work on new practices and teaching challenges together, they will reveal different teaching styles and experiences, express varied perspectives, and stimulate reflection and professional growth. The two case studies discussed in this chapter raise questions about how lecturers participate and learn in their professional development programmes and how to structure such collaboration to maximise lecturer learning.

\section{FUTURE RESEARCH DIRECTION}

There is still a great deal to be thought about, debated, and researched in the area of international involvement in online academic development programmes. In particular, more case studies of the flow-on effects of online academic development and the inclusion of external participants to online student learning programmes need to be 
written. As part of the former, it may be important to explore large-scale rollouts in the undergraduate curriculum to move toward a more sustainable training and development culture in an institution. So, too, it would be useful to have more case studies of long-term teaching and research collaborations between academics that have occurred as a result of interacting with external participants in online academic development programmes. There also need to be more intensive evaluations of the efficacy of this approach and more longitudinal studies to confirm its effectiveness.

\section{CONCLUSION}

This chapter has argued that the impact of international collaboration in online academic development programmes was important in these case studies. We have argued that the quality of online academic development programmes was enhanced by involving national and international guests in online discussions. A review of the literature in the theoretical and practical field of academic development and intra-institution international collaboration suggested that the presence and participation of guest speakers was important because it would allow diverse perspectives to be explored and debated. This chapter indicates how this strategy can be effectively applied to the online teaching environment, which links with the aims of this book to support academic staff in experimenting with e-learning and to value e-teaching. In particular, these case studies demonstrated that international collaboration in online academic development programmes enhances participants' abilities as teachers to help their own students recognise and investigate their assumptions, develop respectful listening and other communication skills, increase their cognitive agility, develop their capacities for critical thinking and synthesizing information and viewpoints, and increase their tolerance for ambiguity or complexity in various topics. As a result, it emphasises the importance of teachers or lecturers experiencing e-learning from a learner's perspective before engaging in e-teaching, which is a key theme of this book.

While there is still a great deal of research needed into this issue, this chapter has confirmed a number of implications of incorporating national and international guest lecturers into academic development programmes that enhance online learning and teaching and strengthen an international academic development community of practice.

\section{REFERENCES}

Abrami, P., Bernard, R., Wade, A., \& Schmid, R. (2006). A review of e-learning in Canada: A rough sketch of the evidence, gaps and promising directions. Canadian Journal of Learning and Technology, 32(3), 119-139. Retrieved April 18, 2006, from http://www.cjlt.ca/content/vol32.3/ abrami.html

Agostinho, S., Lefoe, G., \& Hedberg, J. (1997, July 5-9). Online collaboration for learning. Paper presented at the Third Australian World Wide Web Conference (AusWeb97), Australia.

Anderson, N., \& Henderson, M. (2004). E-PD: Blended models of sustaining teacher professional development in digital literacies. E-Learning, 1(3), 383-394.

Bowles, M. S. (2004). Relearning to e-learn. Melbourne, Australia: Melbourne University Press.

Brookfield, S. D., \& Preskill, S. (1999). Discussion as a way of teaching: Tools and techniques for university teachers. Buckingham, United Kingdom: The Society for Research into Higher Education \& Open University Press.

ChanLin, L. J., \& Chan, K. C. (2007). Integrating inter-disciplinary experts for supporting problembased learning. Innovations in Education and Teaching International, 44(2), 211-224. 
Cotlar, M., \& Shimabukuro, J. N. (1995). Stimulating learning with electronic guest lecturing. In Z. L. Berge \& M. Collins (Eds.), Computer mediated communication and the online classroom: Vol. 3. Distance learning (pp. 105-128). Cresskill, NJ: Hampton Press.

Donnelly, R., \& O’Brien, F. (2003). Towards the promotion of effective e-learning practice for academic staff development in DIT. Level 3. Retrieved May 20, 2007, from http://level3.dit. ie/pdf/issue1_donnelly_obrien.pdf

Donnelly, R., \& O'Farrell, C. (2006). Constructivist e-learning for staff engaged in continuous professional development. In J. O'Donoghue(Ed.), Technology supported learning and teaching: A staff perspective (pp. 146-159). Hershey, PA: Information Science Publishing.

Donnelly, R., \& O'Rourke, K. (2007). What now? Evaluating elearning CPD practice in Irish thirdlevel education. Journal of Further and Higher Education, 31(1), 31-41.

Ferrier, F. (1992, July 12-15). Notmore of the same stuff: Student dissatisfaction with postgraduate courses. Paper presented at the $15^{\text {th }}$ Annual Higher Education Research \& Development Society of Australasia Conference, Sydney, Australia.

Gibbs, G. (2004, June 21-23). The nature of educational development in a changing context. Keynote Presentation at the International Consortium for Educational Development Conference, Ottawa, Canada.

Harasim, L. (1989). On-line education: A new domain. In R. Mason \& A. Kaye (Eds.), Mindweave: Communication, computers and distance education (pp. 50-62). Oxford, United Kingdom: Pergamon Press.

Higgins, K., \& O'Keeffe, D. (2004). An online digital engineering module companion using biomedical applications. Paper presented at the Fourth Annual Irish Educational Technology Users Conference, Waterford, Ireland.
Issroff, K., \& Scanlon, E. (2005). Activity theory and higher education: Evaluating learning technologies. Journal of Computer Assisted Learning, 21, 430-439.

Janes, D. P.(2000). Teaching online in a postgraduate certificate in technology-based distributed learning. Paper presented to the International Online Tutoring Skills (OTiS) E-Workshop. Retrieved May 12, 2000, from http://otis.scotcit. ac.uk/casestudy/janes.doc

Kandlbinder,P.(2000, July 2-5). Peeking under the covers: Understanding the foundations of online academic staff development. Paper presented at the Australian Society of Educational Technology \& Higher Education Research \& Development Society of Australasia Conference, Toowoomba, Australia.

Kearsley, G. (2000). Online education: Learning and teaching in cyberspace. Belmont, CA: Wadsworth/Thomson Learning.

Kezar, A. (2001). Understanding and facilitating organisational change in the $21^{\text {st }}$ century: Recent research and conceptualisations (ASHE-ERIC Higher Education Report, Vol. 28, No. 4). San Francisco: Jossey Bass.

Knapper, C. (2004, June 21-23). University teaching and educational development: What have we achieved? Keynote Presentation at the International Consortium for Educational Development Conference, Ottawa, Canada.

Knight, P. T. (2002). A systemic approach to professional development: Learning as practice. Teaching and Teacher Education, 18(3), 229241.

Kolb, D. (1984). Experiential learning: Experience as the source of learning and development. Englewood Cliffs, NJ.

Laurillard, D. (2001). Rethinking university teaching: A framework for the effective use of educational technology. London: Routledge. 
Learning and Skills Network. (2007). A professional development framework for e-learning. Gillingham, United Kingdom: Impress.

MacKinnon, D., \& Manathunga, C. (2003). Going global with assessment: What to do when the dominant culture's literacy drives assessment. Higher Education Research \& Development, 22(2), 131-144.

Mainka, C. (2007). Putting staff first in staff development for the effective use of technology in teaching. British Journal of Educational Technology, 38(1), 158-160.

Manathunga, C. (2002). Designing online modules: An Australian example in teacher education. International Journal of Instructional Media, 29(2), 185-195.

McAlpine, L., \& Emrick, A. (2003, August 2630). Discipline-based curriculum development: An opportunity for sustainable collegial faculty development. Paper Presented at the $10^{\text {th }}$ Biennial Conference of European Association for Research on Learning and Instruction, Padova, Italy.

McNaught, C. (2000). Technology: The challenge of change. In R. King, D. Hill, \& B. Hemmings (Eds.), University and diversity (pp. 88-102). Wagga Wagga, Australia: Keon Publications.

McPherson, M., \& Nunes, M. B. (2004). Developing innovation in online learning: An action research framework. London: Routledge Falmer.

Mering, J., \& Robbie, D. (2005, July 4-7). Education and electronic learning: Does online learning assist learners and how can it be continuously improved? Paper presented at the HERDSA Conference, Miri, Malaysia.

Oblinger, D. (2006, September 5-7). Listening to what we're seeing. Keynote Presentation at ALTC, Edinburgh, United Kingdom.

Oblinger, D., \& Oblinger, J. (Eds.). (2005). Educating the Net generation. Educause.
Panda, S., \& Juwah, C. (2006). Professional development of online facilitators in enhancing interactions and engagement: A framework. In C. Juwah (Ed.), Interactions in online education: Implications for theoryand practice (pp. 207-227). London: Routledge.

Rodger, S., \& Brown, T. (2000). Enhancing graduate supervision in occupational therapy education through alternative delivery. Occupational Therapy International, 7(3), 163-172.

Salmon, G. (2000). E-moderating: The key to teaching and learning online. London: Kogan Page.

Schön, D. (1990). Educating the reflective practitioner. San Francisco: Jossey Bass.

Seely Brown, J. (2000). Growing up digital. Change, 32(2), 10-11.

Sense, A. (2007). Learning within project practice: Cognitive styles exposed. International Journal of Project Management, 25(1), 33-40.

Sharpe, R. (2004). A typology of effective interventions that support e-learning practice. JISC.

Shivkumar, S. (2006, September 15-17). Strategies for improving elearning effectiveness. Paper presented at the International Workshop on ELearning for Adult Continuing Education.

Surry, D., \& Land, S. (2000). Strategies for motivating higher education faculty to use technology. Innovation in Education and Training International, 37(2), 145-153.

Thompson, K. (2001). Constructivist curriculum design for professional development. Australian Journal of Adult Learning, 41(1), 94-109.

Weaver, D., Chenicheri, S. N., \& Spratt, C. (2005, November 30-December 1). Evaluation: WebCT and the student experience. Paper presented at Making a Difference: Evaluations and Assessment Conference, Sydney, Australia. 
Wenger, E. (1998). Communities of practice: Learning, meaning and identity. Cambridge, United Kingdom: Cambridge University Press.

Wisker, G. (2000, April 23-24). Cross-cultural research supervision and research at a distance: Issues for postgraduate students and supervisors. In M. Kiley \& G. Mullins (Eds.), Quality in Postgraduate Research: Making Ends Meet. Proceedings of the 2000 Quality in Postgraduate Research Conference, Adelaide, Australia (pp.43-49). Adelaide, Australia: University of Adelaide, Centre for Learning and Professional Development (CLPD).

Zuber-Skerritt, O. (1992). Professional development in highereducation: A theoretical framework for action research. London: Kogan Page.

\section{ADDITIONAL READING}

The following is a listing of useful references on the key issues identified in this chapter categorized under the following headings: Postgraduate Research Supervision, Blended Learning Environments, Online Academic Development, and Designing Online Collaboration.

\section{Postgraduate Research Supervision}

Pearson, M. (2000, April 13-14). Flexible postgraduate research supervision in an open system. In M. Kiley \& G. Mullins (Eds.), Quality in Postgraduate Research: Making Ends Meet. Proceedings of the 2000 Quality in Postgraduate Research Conference, Adelaide, Australia (pp. 103-118). Adelaide, Australia: University of Adelaide, Centre for Learning and Professional Development (CLPD).

Pearson discusses the difficulties supervisors face in adapting to use new technology to communicate with students in online modes of learning, and argues that successful supervision of remote students should still involve some traditional methods such as occasional face-to-face meetings.

Rodger, S., \& Brown, G. T. (2000). Enhancing graduate supervision in occupational therapy education through alternative delivery. Occupational Therapy International, 7(3), 163-172.

Rodger and Brown's study provides a comprehensive exploration of the issues and challenges both students and supervisors experience in remote supervision. They recommend a number of helpful strategies for effective remote supervision.

Stacey, E. (1997). A virtual campus: The experience of postgraduate students studying through electronic communication and resource access. UltiBASE.

Stacey's article explores the usefulness of establishing online discussion forums where students can discuss their research with each other. Stacey found that both students and staff regarded the online programme as an invaluable tool in helping remote students to feel motivated to continue with their studies.

Wisker, G. (2000, April 23-24). Cross-cultural research supervision and research at a distance: Issues for postgraduate students and supervisors. In M. Kiley \& G. Mullins (Eds.), Quality in Postgraduate Research: Making Ends Meet. Proceedings of the 2000 Quality in Postgraduate Research Conference, Adelaide, Australia (pp. 43-49). Adelaide, Australia: University of Adelaide, Centre for Learning and Professional Development (CLPD).

Wisker examines a group of international students studying in Britain and then returning home to various countries to complete their higher degree studies by distance. She explores the challenges experienced by both remote students and supervisors and recommends several ways to counteract these issues. 
Wright, T. (2003). Postgraduate research students: People in context? British Journal of Guidance and Counseling, 31(2), 209-227.

Wright identifies a number of problems students experience in studying for higher degrees in research in remote or flexible learning modes. Wright argues that to ensure a smooth supervisor-student relationship, supervisors and students should write out a contract explaining what each person expects from the other, regular progress reviews should occur, and appropriate levels of training and support should be put in place by universities for supervisors.

\section{Blended Learning Environments}

Littlejohn, A., \& Pegler, C. (2007). Preparing for blended e-learning. London: Routledge.

Of particular relevance to this current work is Chapter VI on environments to integrate activity blends. It recognises that blended problem-based learning is a complex construct and concept and involves detailed planning and implementation by the educator.

Savin-Baden, M. (2006). The challenge of using problem-based learning online. In M. Savin-Baden \& K. Wilkie (Eds.), Problem-based learning online (pp. 3-13). Maidenhead, United Kingdom: Open University Press.

This text is useful for providing the educator's perspective on a range of key issues for designing and implementing problem-based learning in a blended or fully online environment. It is aimed at the development of an online pedagogy for PBL.

Reinmann, G., Macdonald, J., Donnelly, R., Fransen, J., \& Poldner, E. (2007, August 28-September 1). Blended learning in higher education: Theory and praxis. Paper presented at the Symposium for EARLI 2007, Budapest, Hungary.
This paper provides evidence from qualitative studies of blended learning in practical situations drawing on tutors' and students' perspectives contrasted with theoretical ideas.

Uden, L., \& Beaumont, C. (2006). Technologyand problem-based learning. Hershey, PA: Information Science Publishing.

This is a practical text that provides a comprehensive overview of what is involved in integrating different learning technologies with a form of inquiry-based learning such as PBL.

Ziegler, M., Paulus, T., \& Woodside, M. (2006). Creating a climate of engagement in a blended learning environment. Journal of Interactive Learning Research, 17(3), 295-318.

This paper describes the conversational interactions of one online learning group. A climate of engagement emerged from the data analysis as the overarching theme, capturing the essence of the participants' online interactions. Four aspects were found to constitute this climate of engagement: engaging in the online environment, engaging in dialogue, engaging as a group, and engaging in the content. A model of engagement is also proposed that captures the dynamic nature of these participants' interactions.

\section{Online Academic Development}

Donnelly, R. (in press). Virtual problem-based learning communities of practice for teachers and teacher educators: An Irish higher education perspective. In C. Kimble \& P. Hildreth (Eds.), Communities of practice: Creating learning environments for educators (Vol. 2, pp.). Charlotte, NC: Information Age Publishing.

This chapter explores problem-based learning in a virtual environment, concentrating specifically on how it is used to form and maintain a community of practice for educators in higher education. 
Donnelly, R., \& O'Farrell, C. (2006). Blended e-learning for continuous professional development of academic staff. In J. O'Donoghue (Ed.), Technology supported learning and teaching: A staff perspective (pp. 146-159). Hershey, PA: Information Science Publishing.

This chapter discusses a 4-week blended professional development course for higher education lecturers on e-learning, and highlights the need for streamlined learning experiences that deliver essential topics and learning materials in readily accessible formats. It is believed a central challenge here is to create and sustain quality learning environments of enduring value for teachers.

Panda, S., \& Juwah, C. (2006). Professional development of online facilitators in enhancing interactions and engagement: A framework. In C. Juwah (Ed.), Interactions in online education: Implications for theory and practice (pp. 207-227). London: Routledge.

This chapter highlights the increased use of the Web for learning and teaching and argues that it has necessitated a reexamination of some of the issues with e-learning and the professional development of academic staff engaged in an online facilitation role.

\section{Designing Online Collaboration}

Price, L., Richardson, J., \& Jelfs, A. (2007). Face-to-face versus online tutoring support in distance education. Studies in Higher Education, 32(1), 1-20.

This paper explores effective online interaction and conceptions of online tutoring in distance learning environments.
Koschmann, T. D. (2002). Introduction to special issue on studying collaboration in distributed PBL environments. Distance Education, 23(1), 28-39.

This is an article that was very helpful in looking at how collaboration can be designed for and supported in an online PBL context.

Jones, C., Cook, J., Jones, A., \& De Laat, M. (2007). Collaboration. In G. Conole \& M. Oliver (Eds.), Contemporary perspectives in e-learning research: Themes, methods and impact on practice (pp. 74-189). London: Routledge.

This chapter focuses on the concept, practice, and research of collaboration. The complete text provides a strong theoretical foundation for the teacher in higher education wishing to explore e-learning; it is research based and considers implications for practice.

McConnell, D. (2006). E-learning groups and communities. Maidenhead, United Kingdom: The Society for Research into Higher Education \& Open University Press.

This book discusses approaches to online course design from a specific communities and group learning perspective.

McDonald, J., \& Mayes, T. (2005, June 24-26). Pedagogically challenged: A framework for the support of course designers in an Australian distance learning university. In CRLL Conference Proceedings (Vol. 2, pp. 397-404). Stirling, Scotland: The University of Stirling.

This is a very popular framework proposing a pedagogy for designing interaction in online courses. 